Saadi M.D. Al-Nuzal

Environmental Research Center, University of Technology Baghdad, Iraq. saaddhaher@yahoo.com

\author{
Salih A. Al-Bakri \\ Environmental Research \\ Center, University of \\ Technology Baghdad, Iraq.
}

Sarah D.A. Zankana

Received on: $21 / 9 / 2018$

Accepted on: 21/05/2019

Published online: 25/06/2019
Egypt, Cairo, 24-28 November 2018

\section{Environmental Impact Assessment for Modern Brick Factory in Baghdad, Iraq}

Abstract- The environmental and social impacts of a bricks factory was evaluated and the information's have been collected from a community questionnaire, as well as the analysis quadrilateral (SOWT) strategic for default modern bricks factory. The results devolve toward the manufacture of bricks with a modern and environment friend technology showed the extent of the community's awareness about contaminants posed by traditional brick plants. The analysis of the strategic quadrilateral project gave positive results in terms of overcome strength elements and of weakness in the internal environment and opportunities to overcome threats in the external environment for the modern factory. The study summarizes number of recommendations concerning, the most important use of modern technologies to reduce pollutants outside of the brick factories and alternatives and environmental monitoring plan for the project so as to ensure that the protection of the surrounding environment.

Key words: Environmental Impact Assessment; Bricks factory; questionnaire analysis; pollutants; and environment friend technology.

How to cite this article: S.M.D. Al-Nuzal, S.A. Al-Bakri and S.D.A. Zankana, "Environmental Impact Assessment for Modern Brick Factory in Baghdad, Iraq," Engineering and Technology Journal, Vol. 3, Part C, No. 3, pp. 377-384, 2019.

\section{Introduction}

Bricks have been manufactured in Iraq as early as the Mesopotamian, Egyptian, and Roman periods, and best examples can be found before the fourth century in Mesopotamia [1-2]. Even after the recent development of the technology of brick manufacture, still there are need for further developments in the environmental management, which may include solid and liquid waste disposal, water supply and distribution, energy generation, effects on the local wildlife species, extraction of the materials and transportation [1 - 5]. Virgin resources may be mined from riverbeds and hillsides to serve brick industry leaving mines areas un-reclaimed. Environmental degradation accompanies such mining activities remains after the mines cease operations, leaves scars on the landscape [6-8]. These procedures involve the systematic identification and evaluation of the impacts of any project process on the environment [9-10]. Commercial exploitation of these resources often leads to various environmental problems. If clay mines are not properly filled up, they can collect water and allow mosquitoes to breed. Extensive sand mining can lower the river- beds and allow salt-water intrusion inland. Therefore, the development of many alternative walling materials as possible will be of immense benefit to minimize the bad impact on the environment [11-12]. Therefore, it has necessary to do
Environmental Impact Assessment (EIA) of a brick industry more with physical base. It may help to solve soil related environmental problems grown by the industry. Firstly, it needs the reduction in use of soils. Utilization of solid waste with soils as raw material can support to brick industry for its sustainability as a base of green production .

The present study aimed to evaluate environmental problems connected with brick industry, and the main points will be mentioned by assessing the environmental and social impacts of the brick factory, such a way to reach for regulations slimmed down from what it was in the past. That will include new evaluation of such projects, and in which the additions serve and benefit the community, and find new alternatives to protect the society in the area, targeting to frontier of the green industry and economy.

\section{Material and Methods}

\section{Study Area}

Al-Nahrawan suburban is located at $65 \mathrm{Km}$ southeast of the capitol Baghdad. There are 259 brick factories, exploited by the private sector, distributed in the area, all of them run by heavy-fuel (black oil). Each one consists of two major parts; the oven and a furnace, where fuel combustion inside supplied with chimney with a height of 10-15 meters. The combustion emission derived out through the chimney with help 
of fans directly to the atmosphere. Its area is 40000 acres $(100 \mathrm{Km} 2)$. It is a flat area and rises nearly about 34 meters above sea level. It is located between the two great circles $\left(33^{\circ} 45^{\prime} 00^{\prime \prime} \mathrm{N}-33^{\circ} 17^{\prime} 00^{\prime \prime} \mathrm{S}\right)$ and two longitudinal circles of $\left(45^{\circ} 55^{\prime} 00^{\prime \prime} \mathrm{E}\right)$ and $\left(44^{\circ} 35^{\prime}\right.$ 00 ” W) [13].

\section{II. $\mathrm{CO}_{2}$ emission}

The consumption of black oil by Al-Nahrawan brick factories during the years 2013 and 2014 is of approximately 731790, 713628 thousand liters, respectively. The total estimated of $\mathrm{CO}_{2}$ gas emission is approximately, 2173864.155 and 2119911.9 thousand Ton, for a total of factories in the study area [14].

\section{Questionnaire and the collection of information}

A questionnaire study is prepared after studies of the determinants and the special factor of bricks environmental legislation. It include nineteen paragraph, and distributed (200) questionnaire on fifty persons of four groups were selected in this area viz. workers, teachers, under graduate students, and citizens affected by the project, as well as a sample of the general community from each group, it was a three-gradation resolution as Likert system (triple), where grades were distributed as follows: agree, 3; disagree, 2; and I don't know, 1. The statistical analysis were presented in Table 1, and the related calculation of the weighted average and the percentage of each paragraph in each of the four groups, where this promotes the work to move forward to establish new projects for the bricks production friend of environment to reduce the impact on surrounding environmental.

\section{SWOT Analysis}

Strengths, weaknesses, opportunities, and threat analysis Quadrilateral strategic analysis contribute to a special factors, the external environment analysis, and those related to the internal environment, in order to access the existing external environmental of opportunities and/or threats, and existing internal environment of the points of strength and/or weakness as shown Table 2 and Figure 2. It can be defined as a planning process to identify the strengths of internal and external environment of opportunities and threats for the project and weaknesses, and is the main goal of the SWOT analysis is to clarify the strategies that describe the appropriate and are compatible with the capabilities of the project to meet the surrounding environment requirements of resources, so by studying the internal and external factors positive and negative ones for the modern brick plant proposed the opportunities and risks SWOT/analysis of strengths and weaknesses, as shown Tables 2 and 3.

\section{Data analysis and results and EIA}

Through the examination of the nineteen questions of the questionnaire for four groups, the average weights for the first group (workers) is $2.02-2.9$ with (67.33 - $96.67 \%)$. The highest weight, while the question about "working on protective equipment" is the lowest.

\section{The questionnaire}

Through analysis of the 19 paragraphs of the questionnaire for four sample sa shown Table 4 , it is noted that paragraph 13 about "establishing a new factory will provide job opportunities to the people of the surrounding area", got the highest percentage and paragraph 6 about "factory adversely affect the environment" is the lowest. As in Figure 1.

The average weight of second group (mostly lecturer and under graduate) records $2.16-2.82$ with (72 - 94 $\%$, where the question about "the use of modern technologies in the production of bricks operations alleviate the negative effects on the environment" the highest weight. Probably this reflect the believe of well-educated people in the usefulness modern technology. Question 11 "committed to working on protective equipment" got the lowest weight, almost similar to believe of workers. The third group (citizens affected by the project) shows a weight of $1.78-2.8$ (59.33 - $93.33 \%$ ). The question about "establishing a new factory will provide job opportunities to the people of the surrounding area", with the highest weight, definitely this is grantee for their future living. Similar to the previous group, the lowest weight is for the question about "working on protective equipment. The fourth group (general community) showed almost similar to previous third group average weights of $1.86-2.76$ with $(62-92 \%)$ for the question about "the establishment of the factory will provide job opportunities to the people of the surrounding area" with the highest weight. They gave the lowest weight for the question, "factory adversely affect the environment". 
Table 1: The statistical analysis of the questionnaire

\begin{tabular}{|c|c|c|c|c|c|c|c|c|c|c|c|c|c|c|c|c|c|c|c|c|}
\hline \multirow[t]{3}{*}{$\begin{array}{l}\text { The type } \\
\text { of sample }\end{array}$} & $\begin{array}{l}\text { NO. } \\
\text { Paragraph }\end{array}$ & 1 & 2 & 3 & 4 & 5 & 6 & 7 & 8 & 9 & 10 & 11 & 12 & 13 & 14 & 15 & 16 & 17 & 18 & 19 \\
\hline & $\begin{array}{l}\text { average } \\
\text { weights }\end{array}$ & 2.58 & 2.44 & 2.61 & 2.45 & 2.42 & 2.35 & 2.51 & 2.40 & 2.13 & 2.45 & 2.06 & 2.40 & 2.63 & 2.31 & 2.53 & 2.51 & 2.52 & 2.45 & 2.54 \\
\hline & percentage & 85.83 & 81.17 & 86.83 & 81.50 & 80.50 & 78.33 & 83.50 & 80.00 & 70.83 & 2.45 & 68.67 & 79.83 & 87.67 & 77.00 & 84.33 & 83.67 & 83.83 & 81.50 & 84.50 \\
\hline \multirow[t]{2}{*}{ Working with specialty } & $\begin{array}{l}\text { average } \\
\text { weights }\end{array}$ & 2.86 & 2.70 & 2.86 & 2.56 & 2.78 & 2.68 & 2.74 & 2.38 & 2.16 & 2.82 & 2.02 & 2.66 & 2.58 & 2.22 & 2.50 & 2.86 & 2.90 & 2.48 & 2.86 \\
\hline & percentage & 95.33 & 90.00 & 95.33 & 85.33 & 92.67 & 89.33 & 91.33 & 79.33 & 72.00 & 94.00 & 67.33 & 88.67 & 86.00 & 74.00 & 83.33 & 95.33 & 96.67 & 82.67 & 95.33 \\
\hline \multirow[t]{2}{*}{$\begin{array}{l}\text { Lecturer and under } \\
\text { graduate }\end{array}$} & $\begin{array}{l}\text { average } \\
\text { weights }\end{array}$ & 2.66 & 2.60 & 2.68 & 2.52 & 2.78 & 2.80 & 2.80 & 2.76 & 2.40 & 2.70 & 2.16 & 2.50 & 2.38 & 2.54 & 2.70 & 2.72 & 2.42 & 2.82 & 2.74 \\
\hline & percentage & 88.67 & 86.67 & 89.33 & 84.00 & 92.67 & 93.33 & 93.33 & 92.00 & 80.00 & 90.00 & 72.00 & 83.33 & 79.33 & 84.67 & 90.00 & 90.67 & 80.67 & 94.00 & 91.33 \\
\hline \multirow[t]{2}{*}{$\begin{array}{l}\text { citizens affected by the } \\
\text { project }\end{array}$} & $\begin{array}{l}\text { average } \\
\text { weights }\end{array}$ & 2.38 & 2.34 & 2.52 & 2.34 & 2.02 & 2.06 & 2.40 & 1.96 & 2.06 & 2.30 & 1.78 & 2.26 & 2.80 & 2.22 & 2.54 & 2.42 & 2.40 & 2.22 & 2.04 \\
\hline & percentage & 79.33 & 78.00 & 84.00 & 78.00 & 67.33 & 68.67 & 80.00 & 65.33 & 68.67 & 76.67 & 59.33 & 75.33 & 93.33 & 74.00 & 84.67 & 80.67 & 80.00 & 74.00 & 68.00 \\
\hline \multirow[t]{2}{*}{ general community } & $\begin{array}{l}\text { average } \\
\text { weights }\end{array}$ & 2.40 & 2.10 & 2.36 & 2.36 & 2.08 & 1.86 & 2.08 & 2.50 & 1.88 & 1.98 & 2.28 & 2.16 & 2.76 & 2.26 & 2.38 & 2.04 & 2.34 & 2.26 & 2.50 \\
\hline & percentage & 80.00 & 70.00 & 78.67 & 78.67 & 69.33 & 62.00 & 69.33 & 83.33 & 62.67 & 66.00 & 76.00 & 72.00 & 92.00 & 75.33 & 79.33 & 68.00 & 78.00 & 75.33 & 83.33 \\
\hline
\end{tabular}

\section{Table 2: The SWOT analysis of the project}

\begin{tabular}{|c|c|c|}
\hline \multirow[b]{2}{*}{ Internal } & Strength (S) & Weaknesses (W) \\
\hline & $\begin{array}{l}\text { It will be a unique technically advanced factory due to the presence of small traditional factories in the region. } \\
\text { It will facilitate construction needs by providing the most basic and needed construction element. } \\
\text { Newcomer fast start to bring feasible profit, no internship necessary before Hiring. } \\
\text { Simple techniques can be learned fast - low costs of training customers. } \\
\text { Easy available workforce. } \\
\text { Provides services to workers. } \\
\text { Operates electric control system. } \\
>\text { Founder within the rules and regulations. } \\
\text { Founder of the environmental system (no need to mitigate the protection significantly). } \\
>\text { Use less water in the production process. } \\
>\text { Use the high temperatures that resulting from combustion in the drying. } \\
>\text { Use the heavy fuel. } \\
>\text { Less time per meal production when compared with the traditional factories. }\end{array}$ & $\begin{array}{l}\text { Uneducated and unskilled labour. } \\
>\text { Maintenance and spare parts. }\end{array}$ \\
\hline \multirow{3}{*}{ External } & Opportunities $(\mathrm{O})$ & Threats (T) \\
\hline & $\begin{array}{l}\text { The production cost of the bricks is less than the cost in other traditional factories. } \\
\text { The need for material produced. } \\
\text { The production of low-price material. } \\
\text { Availability of raw materials. } \\
\text { Provide material combustion (black oil). }\end{array}$ & $\begin{array}{l}\varnothing \text { The project area is within the determinants of location } \\
\text { but it is contaminated and effect on the project. } \\
\varnothing \text { Brick factories may start to compete. } \\
\varnothing \text { Growing costs of firing materials. }\end{array}$ \\
\hline & Positive & Negative \\
\hline
\end{tabular}


Table 3: The results of the SWOT analysis

\begin{tabular}{|l|l|l|}
\hline \multicolumn{1}{|c|}{ Internal } & Strength (S) & Weaknesses (W) \\
\hline Opportunities & $\begin{array}{l}\text { (SO) } \\
\text { The total strength points (13) with the } \\
\text { opportunities (5), Eighteen factor consists of } \\
\text { the establishment of the project enhances the } \\
\text { growth and expansion. }\end{array}$ & $\begin{array}{l}\text { (WO) } \\
\text { The weakness of the internal factors of the project two } \\
\text { matched five opportunities from external factors for the } \\
\text { project that points to overcome weaknesses opportunities } \\
\text { on three clear chances and supports the development and } \\
\text { improvement of the project. }\end{array}$ \\
\hline $\begin{array}{l}\text { Threats } \\
\text { (ST) } \\
\text { Comparing the thirteen strengths with the two } \\
\text { threats, This difference is eleven points of } \\
\text { strength, which overcomes the positive points } \\
\text { on the negative of what enhances the stability } \\
\text { of the project. }\end{array}$ & $\begin{array}{l}\text { (WT) collecting two weaknesses with the three threats they } \\
\text { consist of five negative points when compared with the } \\
\text { fifteen positive point's difference is ten positive points } \\
\text { and in doing so less negative effects on the project. }\end{array}$ \\
\hline
\end{tabular}

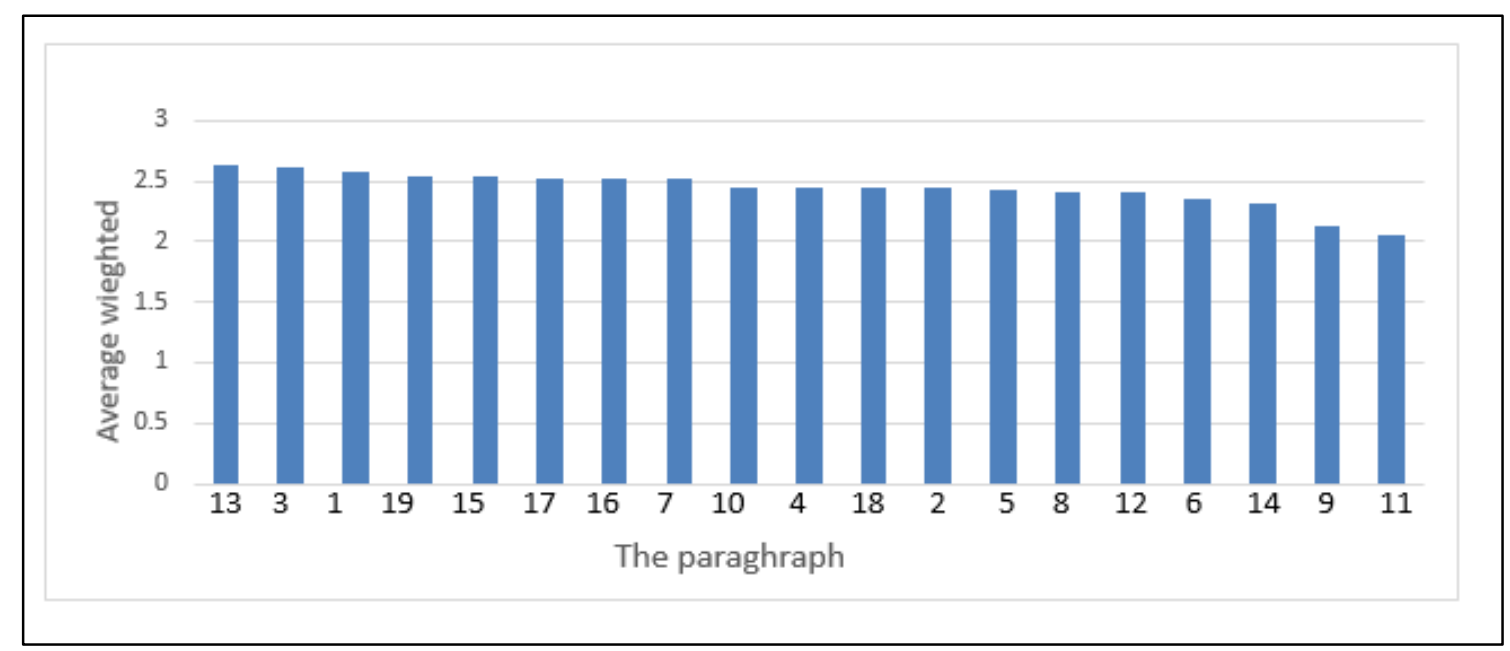

Figure 1: Average of total weight of nineteen questions for four groups of 200 participants.

\section{SWOT Analysis}

A.Components of the project modern Brick Factory.

B. Quarry.

C. The production of the raw material that contains the following equipment Lounge: Primary crusher, Feeding Box importer made of iron in a hopper feeder is used for the processing of the soil continuously, Wet pan Mill foreign origin electricpowered and running on the wet milling of dust equipped with feeding Box, Mill Roller electricpowered for grinding soil, Clay distributor belt with magnetic separator, Mixer (double - shaft mixer), Belt conveyor moves the soil prepared for the production to the aging storage, Aging storage and The processing excavator( Bucket Excavator for aging storage).

D.Manufacturing and forming equipment: Feeding tank is equipped with a belt conveyor is made of rubber and is used for the storage and the processing clays continuously, Roller mill is one of the necessary equipment for grinding clays containing tow rollers rotating in the opposite direction, Clay distributor with magnetic separator, Rotary clay shredders, de- airing
Extruder, Electrical system, Cutting system and multi- wire cutting system for solid bricks.

- Semi-continuous dryer load and unloading system: which consist of load and unloading system as well as semi-continuous dryer system. It include setting system; tunnel kiln; firing system.

- Wagon 's handling lines: consists of three hydraulic pushers for each line and 24-vehicle loading and unloading.

- De-Hacking System: It consists of a wagon unloading three holding heads in the process of transfer of bricks to the conveyor belt to convey to the factory stores.

- Storage Conveyor: Transporting bricks ready for marketing to processing stores where lifted from conveyor belts by forklifts to be put in the right place at the store.

- Kiln wagon ss cleaning system.

- Supervision and control software.

- Electrical system.

\section{The resulting residue and ways to control:}

1. Solid waste: Damaged meals productivity block non-conforming specifications as well as aggrieved because of transport and unloading, 
which is collected and discharged into bodies. Beneficiary and ash output by the combustion processes inside the burning rooms, which are assembled and transported out of the production process so that discharge later in accordance with the mechanisms are supported and particles precipitated by the process of withdrawal of the combustion gases, which accumulate near the industrial air dragline as it is cleaned using a dry cleaning method and discharged in accordance with the mechanisms are supported and unwanted materials generated by the air intake during the secondary mixing process and that is removed from the filter liquidation and collected and discharged in accordance with the mechanisms are supported and aassemble waste resulting from the maintenance of fuel oil tanks as well as the grease used and must be disposed of according to the approved conditions or recycling by the competent authorities.

Table 4: The paragraphs included in the questionnaire

\begin{tabular}{|l|l|}
\hline & The paragraph \\
\hline 1 & The plant produces environmental pollutants. \\
\hline 2 & Brick industry consumes large amounts of water. \\
\hline 3 & Brick industry is depleting the soil. \\
\hline 4 & Side outcomes effect on the surrounding environment. \\
\hline 5 & Regular fuel tanks is required for occupational safety. \\
\hline 6 & Teacher adversely affect the environment. \\
\hline 7 & The existence of afforestation in the brick plant reduces air pollution. \\
\hline 8 & The factory increases the ratio of carbon dioxide, the polluter of the atmosphere. \\
\hline 9 & Noise generated from factory sections is high. \\
\hline 10 & Electric generator is placed in special rooms equipped with silencers. \\
\hline 11 & It is committed to working on protective equipment. \\
\hline 12 & Bricks industry affected residential areas around the plant negatively. \\
\hline 13 & The establishment of the factory will provide job opportunities to the people of the surrounding area. \\
\hline 14 & Factory production fills the local need of bricks. \\
\hline 15 & Brick factory contribute to the prosperity of the economic situation in the country. \\
\hline 16 & The involvement of the employees of the project in advanced training courses among the best performance. \\
\hline 17 & $\begin{array}{l}\text { The introduction of personnel training courses and environmental specialist help in the development of } \\
\text { environmental awareness. }\end{array}$ \\
\hline 18 & $\begin{array}{l}\text { The use of modern technologies in the production of bricks operations alleviate the negative effects on the } \\
\text { environment. }\end{array}$ \\
\hline 19 & Low sulfur fuel is preferred instead of black oil as fuel for bricks. Factory. \\
\hline
\end{tabular}

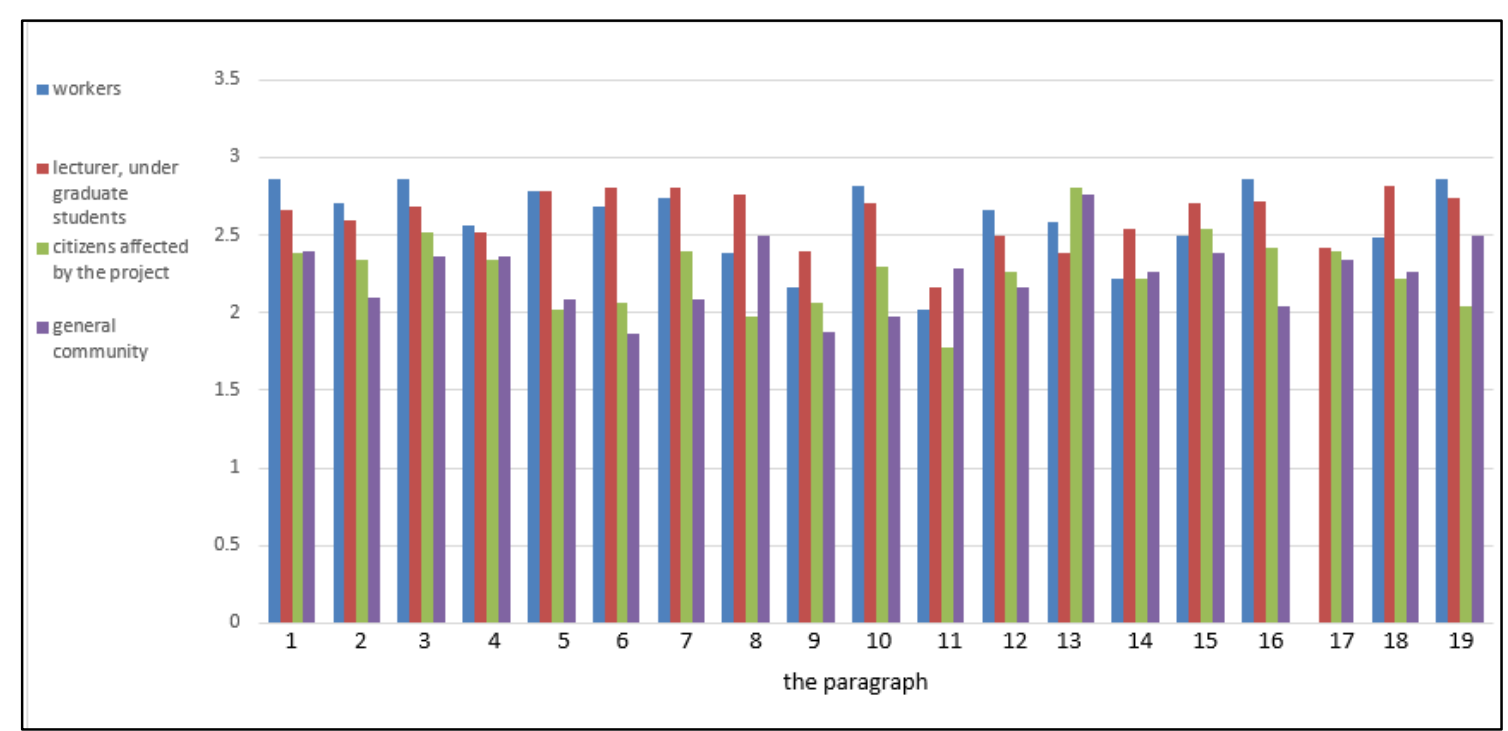

Figure 2: The results of a questioner of four groups of people with concern about brick factories in AlNahrwan, Baghdad

2. Liquid waste: Sewage waters resulting from personal use of employees as well as the use of water to clean up some of the machines and the machines used are discharged through a network cashing housings for storage in tanks floor lined with cement to be transported later by tanker 
trucks to places discharges set by the relevant authorities and fuel spilled (black oil) used in the burning process or (gas oil) used in the operation of the electric generator which in small quantities because of their economic importance and residue oils used to lubricate machinery and equipment used, which requires private assembled improvised to be transferred to specialized agencies recycles used oil.

3. Gaseous waste: The most important gaseous pollutants generated by the project activity the resulting gases and foremost of which is the carbon monoxide-dioxide and oxides of sulfur and nitrogen oxides by combustion that are dispersed using chimneys systemic and airborne dust during the mixing process as well as what was done to the wind from the place of the dust is stored in the open spaces and limited quantities of gases generated by the operation of the generator used to generate electric power and this exceptional case may end up when improved supplies of national electric power supply.

\section{$I V$. Potential environmental impacts and recommendations precautionary}

It must be taken into consideration all the possible environmental impact study before and after the stage commends the project and make recommendations precautions to reduce them according to the engineering and environmental standards adopted in conformity with the safety, health and environmental requirements, which could be clarified.

a. Health safety measures: the preventive measures must undergo workers health to oversee and ensure the absence workers of ailments, especially respiratory diseases and maintain health testimony on that subject workers health surveillance in accordance with the conditions determined by the competent health authorities as well as follow-up and renewal of health certificates for the workers and the need to install a health card on their chests length of the work period. Taking into account the health viewer emergency staff work and request counseling medicine; providing initial aid kit provider instructions extension; providing water cycle And health facilities that cover the floor and walls are tiled and provide the drainage of drainage purely healthy and fit distant away from the components progress of the production process; Providing disinfectants and detergents with the ability to disintegration and biodegradation and use it in a healthy way to take care of water cycles. Must fight against insects, mice, and the reduction of its presence.

b. Regarding safety and civil defense requirements: It requires necessary in the proper preparation for the adoption program that provides necessary for all project facilities as well as protection for workers from the dangers of fire. Based fire-fighting process on the type of material burning.

c. Project environment: Constitute the air pollutants emitted in the form of gases represented in Sulfur oxides that have the ability to Soluble in water vapor molecules in the air, causing acid rain which lead to the corrosion of metals phenomenon And limestone, as well as carbon dioxide effect, where he works on the composition layer to prevent leakage Heat emission from the earth, causing global warming and thus a high degree of ball surface temperature the floor.

d. With regard to the side of the waste: According to the environmental determinants instructions to set up projects and monitor the safety of implementation No (3) for the year 2011 article (81), so it must be that the project includes on-site network for wastewater collection and storage design in basins made of cement concrete and then work on transported by tanker trucks to designated areas with the necessity of solid waste generated from various activities compile and work on sorting and disposal in accordance with the mechanisms accredited.

e. With regard to systems of air conditioning: According to the environmental determinants instructions to set up projects and monitor the safety of implementation No (3) for the year 2011 article (82) with the need to replace the air coolers in the project by the atmospheric air to withdraw, which is loaded with gaseous pollutants as a result of the project activity, to systems for air conditioning and dealing with environmentally friendly gas.

\section{$V$. Monitoring system at the site}

The study of plant design has a special importance, which require being efficient design when using black oil during operating. The best way to monitor the operation of the kiln is the follow-up of the production process of feeding stage until the marketing stage, which is two steps: The first step is to monitor each unit notation problems and try to develop solutions to these problems. The second step is to take samples from each unit and make the necessary tests to determine their efficiency and to evaluate their efficiency in line with national standards. In addition to the above, it is essential to the existence of cyclic control system comes from the donor of the license to monitor and provide the necessary consulting, keeping in mind the following: 
1. The application of good environmental management guide constantly.

2. The plan of Monitor for implementation of precautionary conditions and applied with high accuracy with the need to ensure that all project facilities operate efficiently.

3. Workers monitoring their followers about the conditions of occupational and environmental safety.

4. Constantly working to make the necessary equipment, pumps, tanks, electrical appliances periodic maintenance by the technical staff specialist.

\section{Environmental Management Plan}

The owner of the project to prepare an environmental management plan designed to train cadres of the work and ensure continued commitment to monitor environmental pollutants, in order to determine the effectiveness of mitigation approved and verified the potential expectations of action both to plan waste management or emissions or other environmental influences and their results according to specific criteria so under the standard specifications (ISO 14001) the plan must include the following measures: Audit documentation the final designs of the project to ensure compliance with the project's environmental precautions, taking into account the possibility of development of the project and the dimensions of the future expansion. i. The continuation of environmental monitoring during the operational phase to ensure that the environmental requirements.

ii. Make the modifications required during the operational phase in order to avoid potential environmental impacts.

iii. Encourage cooperation with scientific research institutions and the adoption of engineering and scientific advice in case of the emergence of environmental or unintended effects of problems that require treatment and control.

iv.Spread environmental awareness between the employees of the kiln to its importance in reducing accidents that may bear directly and indirectly on the health and environmental effects.

v. Identifying places which are likely to occur where environmental problems with the need to clarify the indicators that should be reviewed to deduce them.

vi.Managerial preparation program contributes to address problems as they arise in line with the principles of environmental management.

vii. The need to prepare an explanatory diagrams productivity of the process and the potential pollution sources to be the means of evidentiary kilns workers and to increase environmental awareness of workers.

viii. Training staff work and provide the necessary supplies of conformity with the standard specifications followed, that the plan includes the need for continued environmental monitoring of the relevant authorities.

ix. Adoption of a contingency plan and securing supplies and preparing and training the manpower needed to accomplish, which include develop a plan to combat the rodents and insects, and put a contingency plan in the event of a fire or accidental, or the emergence of epidemics.

Moreover, should the environmental situation of the kiln record preparation which defines which includes the type of activity and legislation kiln (Laws regulating licenses) and environmental requirements guide for kiln brick industry and environmental monitoring of the draft program and the results of air pollutants samples and that the results will be recorded in the environmental register and make it available at the Environmental Inspection and solid and liquid waste types and quantities and how to safely dispose of them and those contracted for delivery of these residues.

\section{Alternatives}

For the purpose of treatment greenhouse gas emissions produced by the combustion process and reducing the concentrations of pollutants to the permissible limits according to national standards preferred design of an integrated system of treatment that include: A set of filters for filtering the combustion chambers, and The use of adsorption chemical transformation, and other technologies. Emissions control through the scrubber is placed in the chimney to wash the outside gas.

\section{Conclusions and recommendations}

1- From SWOT analysis, it was concluded that, the strengths and opportunities would balance in favor of best performance of production quality, against the weakness and threat. The industrial process represented by brick factory and tanning factory considered the main reason for high level of air and soil pollutants in Al-Nahrawan area. Community participation is one of the basic items for the development of methodology for assessing the environmental impact and this in turn confirms the importance that stems including the participation of society in the process of development and improvement of the work and performance of the construction and establishment of projects.

2-The results of questioner, in which the participant are inhabitant and workers, revealed that $80 \%$ of them they believe that more brick 
factories increase will increase the emissions of carbon dioxide, while $81.5 \%$ of them recommend modernization of these factories. The official procedure to approve the application should seriously consider the environmental limitations, to ensure the best environmental control over and the pre-protection from of the attack on the environment. The present scientific building block study can be a basic one for future development of such type of industry. As a result of the poor quality of fuel used in combustion processes viz. black oil, which causes air and soil pollution with sulfur compound emission, necessitate the addition of fuel quality enhancer, or the use of better quality fuel, or currently use electricity to keep the environment clean. Issuing legislation and laws to ensure the stringent measures to curb environmental waste that get by the lack of commitment to implement precautionary measures to prevent cases for pollution. Encourage community participations or contributions in all segments, mainly from the foundations of the environmental impact assessment and policy for each different life activities. It is necessary to carry out community and workers awareness, and dissemination of knowledge and education risks and damage caused by environmental pollution, by other executive institutions civil community organizations. Lectures, seminars and workshops in topics of environmental impact and the consequent health and environmental potential risks to humans and the environment, and encourage researchers and their institutions to conduct similar studies. Conduct the environmental assessment of the environmental impacts of contaminated factories prior to their implementation to mitigate or control environmental effects. The designs and activities subject to environmental standards should be considered, with help of the environmental monitoring and surveillance measures. Must change the traditional methods in the face of environmental problems and disasters, and the development of long-term environmental strategy to preserve national wealth and protect it from pollution. As it should be coordination between the concerned authorities in the application of laws and international environmental agreement to reduce duplication of work. Reducing the particles released from the chimneys in the brick factory by using new method to control these particles. Setup a monitoring station permanently in Al-Nahrawan area to know the amount of emission and the concentration of the pollutant. Develop production methods through the application of proposals methods and technology of cleaner production in various industrial processes or using raw materials and supplies environmentally friendly.

\section{Reference}

[1] F. M. Fernandes, P. B. Lourenço, F. M. Castro, "Ancient Clay Bricks: Manufacture and Properties, Materials, Technologies and Practice in Historic Heritage Structures," pp. 29-48, 2010.

[2] P.R.S. Moorey, “Ancient Mesopotamian Material sand Industries: The Archaeological Evidence," Eisenbrauns, Winona Lake, Indiana, Pp. 313-321, 1999.

[3] N.A. Lakho, M.A .Zardari, "Structural properties of baked clay bricks fired with alternate fuels.", Engineering,.Tr aditional manufacturing of clay brick used in the historical buildings of Diyarbakir (Turkey), Vol. 8, Pp. 676-683,2016.

[4] P.B. Lourenço, F.M. Fernandes, F. Castro, "Handmade clay bricks: chemical, physical and mechanical properties," Int. J. Archit. Herit. Conserv. anal. Restor., Vol. 4, Pp. 3858, 2010.

[5] R.W. Richards, "Brick Manufacturing from Past to Present," The American Ceramic Society Bulletin. May, pp. 807-813, 1990.

[6] A.A. Shakir, and A.A. Mohammed, "Manufacturing of bricks in the past, in the present and in the future: a state of the art review," International Journal of Advances in Applied Sciences, Vol. 2, No. 3, Pp. 145-156, 2013.

[7] E. Allen, and R. Hallon, "Fundamental of residential construction," $3^{\text {rd }}$ edition, John Wiley \& Sons, San Francisco, USA, 2011.

[8] S. Deboucha and R. Hashim, "A review on bricks and stabilized compressed earth blocks," Department of civil engineering, faculty of engineering, University of Malaya, Kuala Lumpur, Malaysia, 2011.

[9] R. Therivel, "Strategic Environmental Assessment in Action," $2^{\text {nd }}$ Edition, Earthscan in UK and USA, 2004.

[10] N. Lee and F. Walsh, "Introduction: Strategic environmental assessment: an overview," Journal Project Appraisal, Volume 7, Issue 3, Pp. , 1992.

[11] K. Avinas, "Environmental Impact Assessment of Brick Industry: With Special Focus on Soils," Enrich Environment Multidisciplinary International Research Journal, Vol. 1, Issue 1-3, No. 1-3, 2008

[12] A.H. Al-Khafaji, "Air pollutants effects from brick factories on climate change using geomatics techniques," Thesis, building and construction engineering department, University of Technology, 2016.

[13] S.M.H.A. Shanshal, "The impact of pollution resulted from the tannary and brick factories on soil and water at water at Nahrawan area-eastern Baghdad," Master Thesis, Department of Earth Sciences, Faculty of Science, University of Baghdad, 2004. (in Arabic).

[14] S.M.D. Al-Nuzal, S. A.Al-Bakri, S.D.A. Zankana, Environmental Impact Assessment for Brick Factory in Baghdad, Iraq," Engineering and Technology Journal Vol. 36, Part C, No. 1, 2018 